\title{
Financial Incentive as a Yardstick for Employee Performance: The Case of University of Nairobi
}

\author{
Dorothy Njiraine, $\mathrm{PhD}$ \\ University of Nairobi, Department of Library and Information Science, P.O. Box 30197-00100 Nairobi, Kenya.
}

\begin{abstract}
The paper examines the extent to which financial incentives contribute to employee performance, the case of University of Nairobi. The study was descriptive in nature and investigated financial incentive as a yardstick to assess employee performance at the University of Nairobi. The target population in this study was the non-teaching staff of Nairobi University, whereby stratified sampling technique was applied. The findings of the study revealed that financial incentive as a human resource management practice enhances performance of employees. It also indicated that other factors such as healthcare for the employees, contribute to employees' motivation. Major recommendations is the need for harmonization of the financial incentives as a means to long term objectives and the strategies of the organization. Further research should be explored from the perspectives of effects of human resource management practices on employee turnover and organizational life cycles.
\end{abstract}

Keywords: Human resource management practices, human resource management, financial incentives, pay incentives, employee performance.

DOI: $10.7176 / \mathrm{EJBM} / 11-8-10$

Publication date:March $31^{\text {st }} 2019$

\section{Introduction and background}

According to UNDP (2006) report, incentives and incentive systems are fundamental to developing capacities and translating developed capacities into better performance in organizations. Employee motivation is crucial to Organizations especially in the current dynamic technological environment. Organizations need to maintain their competitive edge by investing in employees' wellbeing in terms of incentives in order to succeed. The United Nations Development Programme (UNDP, 2006) describes incentives as "both the reason for staff to join an organization, and the way an organization rewards and punishes its staff'.Kaiser (2014) argues that incentives are often considered as forms of extrinsic motivation whereby employees tend to perform their jobs well when incentives such as performance pay and bonuses are in place. As Ogutu (2014) contends, the main factors affecting performance in the civil service include low salaries and allowances for the civil servants, lack of equipment and office space, poor compensation, absence of a career-development structure, and poor delegation. The influence of incentives on employee performance with regard to incentive structures, types of incentives and how they are used ranging from wage emoluments, training and promotion procedures and sanctions against poor performance, is in a wanting state (Morgan and Baser, 2007).

Human resources management has diverse definitions, some of which are: a strategic, integrated and coherent approach to the employment, development and well-being of the people in working organizations, while others refer to the process through which management builds the workforce and tries to create the human performances that the organization needs and distinctive approach to employment management which seeks to obtain competitive advantage through the strategic deployment of a highly committed and skilled workforce, using an array of cultural, structural and personnel techniques (Armstrong, 2016:7; Boxall and Purcell, 2016: 7; Storey, 2013). It is clear that human resources management is an important part of today's business management, which incorporates incentives as one of the key factors to enhance employees' performance in organizations.

Organizations have increasingly recognized the potential for their people to be a source of competitive advantage (Pfeffer, 1994). Creating competitive advantage through people requires careful attention to the practices that best leverage these assets. This change in the mindset of executive decision-makers has spurred an increasing body of academic research attempting to reveal a relationship between a firm's human resource practices and its performance. One study identified four factors that draw individuals to the public service: attraction to public policymaking; commitment to the public interest and civic duty; self- sacrifice; and compassion. Another study classified motives for public service into different 'helping orientations': Samaritans (defined by service to individuals in need), Communitarians (community activists), Patriots (who value service to one's country) and Humanitarians (who work for the broader interests of humanity) (UNDP, 2014).

\subsection{Public universities in Kenya}

Higher Education drives and is driven by globalization (OECD 2009). Additionally higher education trains skilled workers and contributes to the research base and capacity for innovation that determine competitiveness in the knowledge-based global economy while facilitating international collaboration and cross-cultural exchange. The crossborder flow of ideas, students, faculty and financing, coupled with developments in information and communication 
technology, are changing the environment where higher education institutions function' (OECD 2009; Okioga et al. 2014).

The public universities are facing fierce competition from both local and foreign institutions. They have to continue to create superior value to survive this competitive onslaught. Demands on the Universities have increased. Various stakeholders are demanding more from the institutions currently than in the past. Continued performance improvement is now a basic requirement.

These and other challenges mean the Public Universities have to embrace change. Effective response will involve the re-thinking of old assumptions of university education that may have worked well in the past but could trap and immobilize the institutions in the future. The external environment within which this role has to be performed has changed dramatically and it has acquired an international character. The external environment of the public universities has continued to change. This means new opportunities and challenges have and will continue to surface.

\subsubsection{University of Nairobi}

The foundation of the University of Nairobi can be traced back to 1947 when the then colonial Government in Kenya put forward a proposal for the creation of a commercial and technical institute in Nairobi. By 1949, it had matured to encompass the three East African countries namely Kenya, Tanzania and Uganda with the intention of providing specialized education for the member countries (UON, 2018). The Royal Technical College of East Africa was issued with a Charter in September of 1951. Around the same time, the Asian Community in the region was also working toward establishing an academy for Commerce, Science and Arts, in commemoration of Mahatma Gandhi. To prevent the replication of efforts, the society spearheading the Gandhi Memorial Academy conceded to work with the colonial Governments of East Africa. As a result in April of 1954, the Gandhi Memorial Academy was integrated into the Royal Technical College of East Africa, and by April of 1956, the college opened its doors to receive the first group of students. (UON, 2018).

The Royal Technical College was elevated to become the second University College in East Africa under the name Royal College Nairobi in 1961. In 1970, the University College Nairobi became the first national university in Kenya and was renamed the University of Nairobi (UON, 2017). As at December 2018, the university had a population of 84,000 students, 2,220 academic staff with PhDs and 5,525 administrative and technical staff(UON, 2018).

\subsection{Statement of the Problem}

Scholars argue that public officials have an intrinsic motivation to serve the public good. Working in the public service sector has been associated with "an attitude, a sense of duty" and "public morality" (Staats, 1988: 601). Low motivation has been cited as a major factor in Africa's human resource crisis. Strategic human resource management practices improve organization's performance (Beer et al, 2005). This approach emphasizes the importance of congruence between human resource activities and organizational objectives. Recent research has focused on the links between human resource management and Employee performance (Guest 2003; 2004; Purcell, 2003), much of the growing body of international literature in the field is built upon the premise that human resource management is linked closely to the emergent strategies, especially of large organizations, both public and private organizations.

The most influential innovative human resource management practices applicable to the health sector is associated with Gould (2002) whereby he summarized these practices as incentive pay, personal training and skill development programmes, and internal promotion.

Existence of leadership problems, inconsistency in application of human resources (HR) policies, complacency and apathy among the work force has been a common phenomenon in many public universities in Kenya. The existence of these anomalies, and the recent clamour for better pay and improvement of the quality of work life by employees in other state owned organizations prompted the researcher to embark on carrying out an investigation into the extent of utilization of financial incentives as a means to employee performance in the selected university.

\subsubsection{Objectives of the Study}

The objective of study was to find out the extent to which financial incentive contributed to employee performance at the University of Nairobi.

\subsubsection{Research Hypothesis}

$\mathrm{H}_{1}$ : There is positive effect of financial incentive on employee performance at the University of Nairobi.

\section{Review of the literature}

Developing economies require effective labour and Human Resource Development for national economic competitiveness, social well-being and political democracy, Riechi (2010). Human resources management as defined by Armstrong (2016) is a strategic and coherent approach of the management of an organization's most valued assets, the people working there who individually and collectively contribute to the achievement of its goals. 
As defined by Storey (2013), human resource management is a distinctive approach to employment management which seeks to obtain competitive advantage through the strategic deployment of a highly committed and skilled workforce, using an array of cultural, structural and personal techniques.

Human resources management practices and systems have been linked to organizational competitiveness, increased productivity, higher quality of work life and greater profitability (Schuler, 2002). In a global economy, competitiveness means the ability to take the most advantageous position in a constantly changing market environment (Pfeffer, 1994). In order for this link to be accomplished between human resources management and organizational success, the role of human resources management must become strategic instead of operational, aligning the human resources function with the strategic needs of the organization (Pickles et al; 1999).

Performance measurement is an essential component of whatever change process is adopted. It can give feedback on the effectiveness of the plans and their implementation (Chow et al., 2008). Both business managers and accountants are keenly aware of the important role performance measurement plays in an organization's planning and control system. Reporting on firms' past performance is one of the fundamental uses of performance measurement system. Traditionally, the focus of performance measurement has been on financial measures such as sales growth, profits, return on investments and cash flows. There is, however, increasing concern among business managers on the over-reliance of financial measures in performance evaluation.

There are a growing number of managers within the public sector who now reason that if employee performance results in enhanced organizational performance, then employees should share in the benefits received. In other words, they feel that workers should be appropriately and equitably rewarded for their effort (Ghosh, 2005). It has been observed that when employees perceive that the only ones benefiting from their diligent efforts are the management team, shareholders, or other parties, they become discouraged. To avoid this, some managers have introduced reward packages in which employees receive enhanced pay based on individual and/or group performance (Mathias, \& Jackson, 2004).

The most common reward scheme is one in which performance is related to pay, such financial incentive schemes can be offered in many ways, but the most effective reward packages tend to be based on multiple performance criteria at the individual and/or organizational levels. In such instances workers receive a percentage bonus in salary based on organizational profitability or efficiency gains. Alternatively individual reward packages are awarded when inter alia, individuals increase their productivity, improve the quality of output (whether a product or service), enhance their contribution to the department or section by making suggestions, and/or cooperate with other members of the workforce (Mullius, 2005).

Financial incentives involves monetary value awarded to employees, either in bulk or monthly payments. Lawzi (1995) lists the benefits accrued by financial incentives as: satisfying basic human needs, improved work performance, the recruitment of their capabilities and increase the level of their competences such as salary, bonuses, allowances, profit sharing and rewards. Financial incentives motivate the individual's desire to work when such wages are appropriate and capable of satisfying his needs. On the other hand, they to have their downtime such as focusing more on individual rather than teamwork, employees feeling neglected, appraisals not meeting the organizations' expectations (Rehman and Ali, 2013)

\section{Research Methodology}

This paper outlines the methodology used in this study. The guiding principles here is the objective of the study. The methodology includes research design, sampling procedure and techniques, data collection procedure and techniques, and data analysis and tools. It was divided into several sections that would cover research design, sampling, instruments of data collection and data analysis techniques.

The study was a descriptive examining financial incentive as a yardstick to assess on staff performance at the University of Nairobi. Financial incentive forms part of human resource practices in public universities that influence employees' performance. According to Gray (2004), descriptive research involves collecting data in order to answer questions concerning the current status of the subject under study.

The target population in this study was the non-teaching staff of Nairobi University. The study population therefore covered all the employees in the middle grades (Grades A - F). The population size for this category of staff is 1318 (University of Nairobi Establishment Plan, 2012).

\subsection{Sample design}

The sampling design impacts both the external and internal validity of the research findings. A pretest piloting was used to test validity and reliability. The internal validity ensured relevance, consistency and coherence of results in relation to the researcher's objectives. The external validity enabled extrapolation of results from sample to other elements. The researcher adopted the probability sampling method. This enabled the researcher to utilize some form of random selection which ensured that different units in the population have equal probabilities of being chosen.

The researcher adopted the stratified sampling technique. The stratified sampling technique produces 
estimates of overall population parameters with greater precision than estimates obtained from other sampling techniques. A purposeful non probability sample, selected subjectively was taken from the target population in the university. The study used convenient non probability sample since study units are easily accessible.

Based on Krejcie and Morgan table (1970), extracted from the division of the National Educational Association Schedule published formula 'Small Sample Techniques', the sample size for this study was 297 based on the population size of 1318 .

\section{Data analysis and discussion of findings}

The analysis was based on the data collected by use of questionnaires which were administered to respondents. This chapter also presents an in-depth analysis of the findings using frequencies, percentages, mean scores, standard deviations and regression analysis. The research was conducted on a sample of 297 respondents from University of Nairobi. However, only 240 questionnaires were returned duly filled in making a response rate of $80.8 \%$, which is above the recommended $50 \%$ by some scholars such as Rubin and Babbie $(2016: 191)$ and Mugenda and Mugenda (2003). Additionally Babbie (2011:289) concurs that a 50\% response rate is acceptable and adequate for analysis and reporting, however $60 \%$ is believed to be good while above $70 \%$ is considered to be excellent, meaning the response rate for this study was above excellent.

The positive response rate was made possible after the researcher personally administered the questionnaires and made further visits to remind the respondents to fill-in the questionnaires. This study made use of frequencies (absolute and relative) on single response questions. On multiple response questions, the study used Likert scale in collecting and analysing the data whereby a scale of 5 points were used in computing the means and standard deviations. These were then presented in tables, graphs and charts (tables have been presented as appendix after the references, while graphs and charts have been excluded in this paper) as appropriate with explanations being given in prose. The analysis is based on the objective that seeks to find out the extent to which financial incentives contributed to employee performance at the University of Nairobi.

\subsection{Demographic information}

\subsubsection{Gender}

From the analysis it is very clear that majority of employees are female. There were $57.6 \%$ were female as opposed to the male who are $42.3 \%$, which may be argued that the University of Nairobi practices equal opportunity employment for both genders as per the constitution of Kenya employment act Cap 226 (2012) and International Labour Organization (ILO, 2018) requirements.

Figure 4.1: Gender

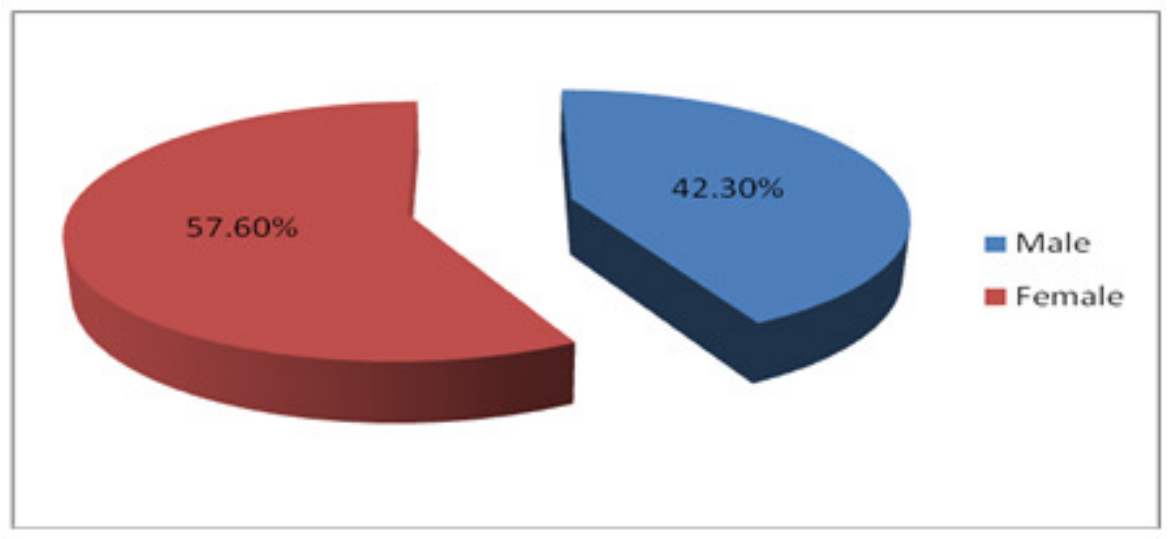

\subsubsection{Age}

The study sought to find out the age of the respondents. It was indicated that $36.8 \%$ of the respondents were between 26 and 35 years, $18.3 \%$ were between 36 and 45 years while $26.7 \%$ were between 18 and 25 years, $12.8 \%$ were between 46 and 55 years while a few 5.4\% were above 55 years. This age distribution was indicative that majority of UON staff are young and the middle aged, which is significant in any organization. This may further be argued from Senge's perspective that an organization is a living community of people with shared responsibilities for effectiveness (Fulmer and Keys, 1998:35). 
Figure 4.2: Age

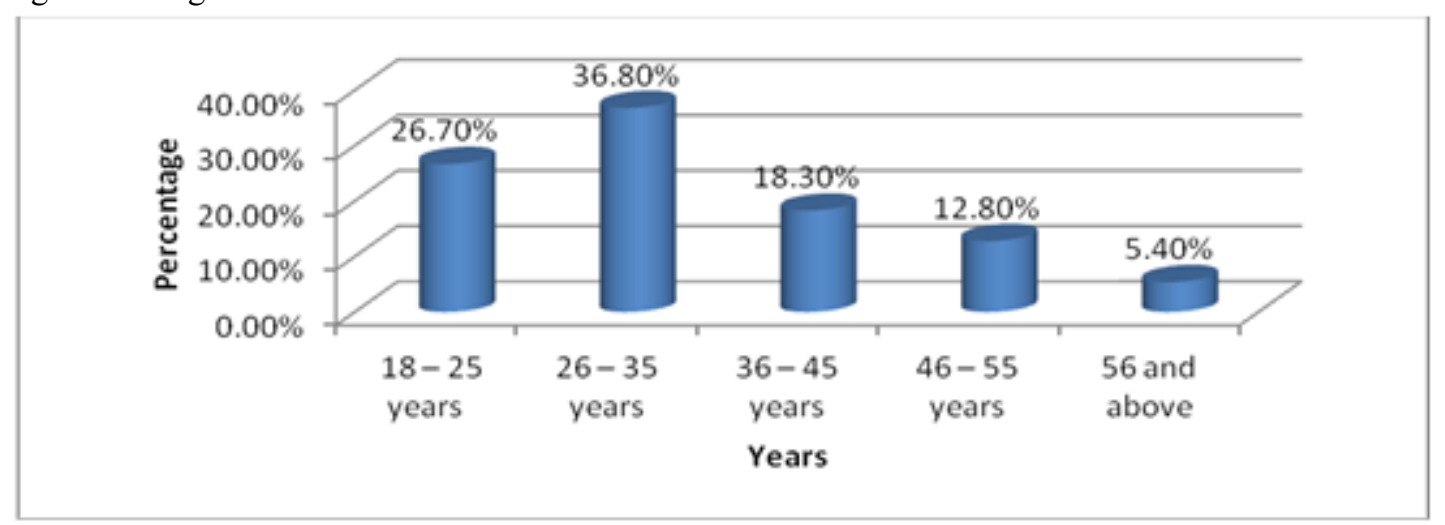

\subsection{Work Experience}

In regard to their experience at work, the majority of the study population, $45.8 \%$ have $4-7$ years' experience. $22.4 \%$, have worked for 8 to 12 years, while another proportion of $12.4 \%$ have work for 13 years and above, few of them $10.2 \%$ have experience of 1 to 3 years. The findings indicate that the majority that comprise $45.8 \%$ joined the university from other institutions hence possess the necessary experience and skills in their respective profession.

Figure 4.3: Work experience

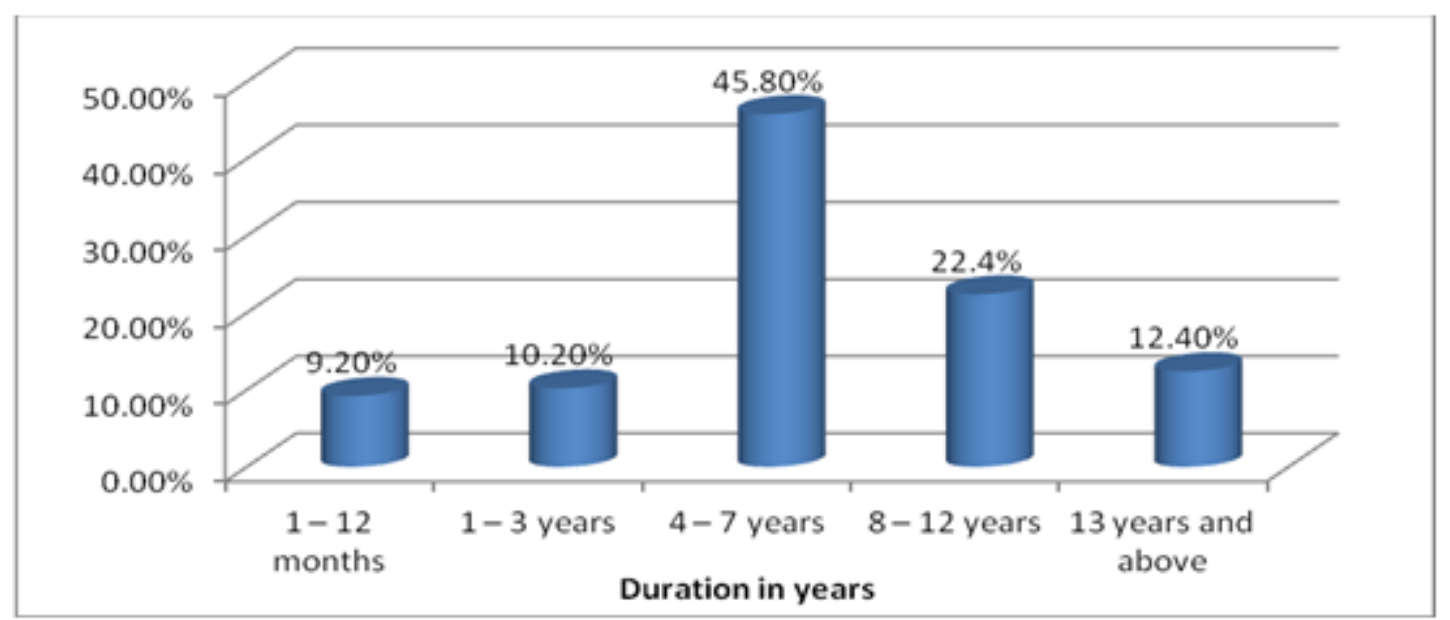

\subsection{Employee performance}

Respondents were asked to rate the level of their performance in the organization. From the findings, the respondents agreed with the given performance measures and this interpreted that UON employee performance fairly good, (Mean $=4.09$, Std. dev $=0.59$ ).

Table 4.1: Employee Performance

\begin{tabular}{|l|c|c|}
\hline & Mean & Std. Dev \\
\hline Innovation and change & 4.09 & 0.72 \\
\hline Customer satisfaction & 4.09 & 0.60 \\
\hline Operating efficiency & 4.08 & 0.57 \\
\hline Financial performance & 4.10 & 0.50 \\
\hline Employee performance (Y) & $\mathbf{4 . 0 9}$ & $\mathbf{0 . 5 9}$ \\
\hline
\end{tabular}

Furthermore, respondents were asked to rate the level of their performance in the organization. From the findings, it was fairly asserted that employees in the organization are recognized, (Mean $=3.44$, Std. $\mathrm{dev}=0.91$ ). Otherwise, the rest of the factors were in agreement, for instance, the fact that employees' personal milestones are recognized in this organization, (Mean $=4.15$, Std. $\mathrm{dev}=0.44$ ); and that organization contributes a sufficient amount for healthcare costs of employees, $($ Mean $=4.03$, Std. $\mathrm{dev}=0.53)$. It was also agreed that employees objectives are matched to that of the organization, (Mean $=4.00$, Std. dev $=0.79$ ). Additionally it may be argued the rate of employee performance as afore-indicated, concurs with the motivation hygiene theory. The theory proposes that certain motivator and hygiene factors can affect job satisfaction and dissatisfaction. The motivators primarily contribute to satisfaction alone while hygiene factors contribute to dissatisfaction alone. 
The theory hypothesizes that satisfaction and dissatisfaction are separate and independent feelings. Considering motivators, a better on the job performance may increase motivation, hence are relatively motivated.

Table 4.2: Rating performance factors

\begin{tabular}{|c|c|c|}
\hline & Mean & Std.Dev \\
\hline Employees in this organization are recognized fairly & 3.44 & 0.91 \\
\hline Evaluation of employee's performance in this organization is carried out fairly & 3.96 & 0.81 \\
\hline Employees' personal milestones are recognized in this organization & 4.15 & 0.44 \\
\hline $\begin{array}{l}\text { Compensation awarded to employees is fair and competitive according to industry } \\
\text { standards }\end{array}$ & 3.89 & 0.72 \\
\hline This organization contributes a sufficient amount for healthcare costs of employees & 4.03 & 0.53 \\
\hline This organization addresses life problems that get in the way of employees performance & 3.98 & 0.64 \\
\hline You are motivated to do your best when working for this organization & 3.99 & 0.79 \\
\hline Your personal objectives match with those of the organization & 4.00 & 0.79 \\
\hline You are planning to pursue any professional advancement & 4.19 & 0.58 \\
\hline
\end{tabular}

\subsection{Influence of Human Resource Management Practices on Staff performance}

Human resources can provide a competitive advantage due to the fact that it is valuable and rare. Imperfectly imitable and has no substitute. Competitors can duplicate competitive advantage obtained via better technology and products but it is difficult to duplicate competitive advantage that is created through improved management of people. The motivation of the research was to establish influence of human resource management practices i.e. incentive pay.

\subsubsection{Incentive pay}

The respondents were asked to give a view of the extent to which incentive pay enhances employee performance. The responses were as follows: $53.7 \%$ gave great extent, $12.6 \%$ very great extent, $10.5 \%$ moderate extent and $6.3 \%$ low extent.

Figure 4.4: Extent influence of incentive pay on performance

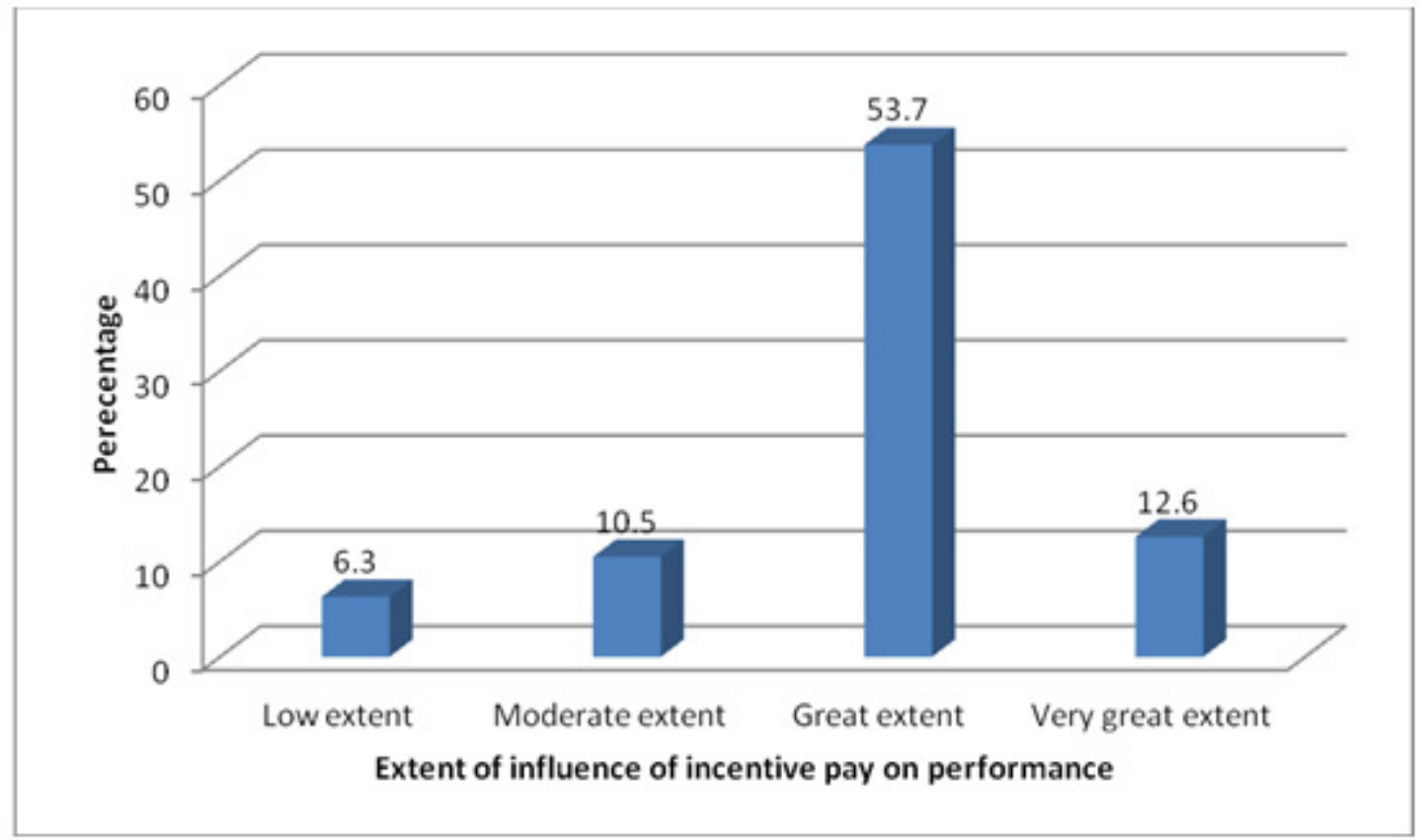

The study also sought to establish influence of incentive pay on performance. It was agreed that bonuses in employees' salaries based on organizational profitability or efficiency gains enhances employee performance, (Mean $=3.95$, Std. dev =0.82). It was also agreed that, workers are appropriately and equitably rewarded for their effort, (Mean $=4.49$, Std. $d e v=0.50)$. It was also agreed that when employees benefit from incentive pay they enhance their output, $($ Mean $=4.46$, Std. $\mathrm{dev}=0.50)$. 
Table 4.3: Influence of incentive pay on job performance of staff

\begin{tabular}{|l|l|l|}
\hline & Mean & $\begin{array}{l}\text { Std. } \\
\text { Dev. }\end{array}$ \\
\hline $\begin{array}{l}\text { Percentage bonuses in employees' salaries based on organizational profitability or } \\
\text { efficiency gains enhances employee performance. }\end{array}$ & 3.95 & 0.82 \\
\hline Workers should be appropriately and equitably rewarded for their effort & 4.49 & 0.50 \\
\hline When employees benefit from incentive pay they enhance their output & 4.46 & 0.50 \\
\hline Individual reward packages are always awarded when individuals increase their productivity & 2.61 & 0.70 \\
\hline
\end{tabular}

\subsection{Correlation matrix table}

From the findings, it was found out that all the predictors showed a positive relationship as indicated in the matrix. The incentive pay showed a positive relationship with employee performance, (Pearson's r=0.393, sig.0.005). It was also established that the independent variable (financial incentive) has some association with the dependent variable (employee performance).

Table 4.4: Correlation matrix table

\begin{tabular}{|l|l|l|l|}
\hline & & \multicolumn{1}{|c|}{ Employee Performance } & Incentives \\
\hline \multirow{5}{*}{ Employee Performance } & Pearson Correlation & 1 & \\
\cline { 2 - 4 } & Sig. (2-tailed) & & \\
\cline { 2 - 4 } & $\mathrm{N}$ & 54 & 1 \\
\hline \multirow{5}{*}{ Financial Incentives } & Pearson Correlation & $.393^{* *}$ & \\
\cline { 2 - 4 } & Sig. (2-tailed) & .005 & 49 \\
\cline { 2 - 4 } & $\mathrm{N}$ & 49 & \\
\hline
\end{tabular}

\subsection{Regression analysis results}

\subsubsection{Model summary}

$\mathrm{R}$ is 0.433 , while $\mathrm{R}$ square is the proportion of variance in the dependent variable (employee performance) which can be explained by the independent variables. This is an overall measure of the strength of association and in this case it is 0.287 . The adjusted $\mathrm{R}$ square is 0.223 showing a relationship between the observed and predicted values of the dependent variable. This indicates that financial incentive accounts for $28.7 \%$ of the employees' performance at the University of Nairobi.

Table 4.5: Regression model summary

Model Summary

\begin{tabular}{|l|l|r|r|r|}
\hline Model & R & R Square & Adjusted R Square & Std. Error of the Estimate \\
\hline 1 & $.433^{\mathrm{a}}$ & .287 & .223 & .97278 \\
\hline
\end{tabular}

a. Predictors: (Constant), incentive pay, internal promotion.

\subsection{ANOVA}

The analysis of variance, sum of squares, degree of freedom (df), mean square, regression and residual values obtained from regression analysis. The mean square is 3.764 . The F static which is regression mean square divided by the residual mean was 3.921. Degree of freedom df, was 3.00. Statistically, the overall relationship was very significant with significant value, $\mathrm{P}$ value $=0.046,(\mathrm{P}<0.05)$

Table 4.6: Regression ANOVA

\begin{tabular}{|c|c|c|c|c|c|c|}
\hline \multicolumn{7}{|c|}{ ANOVA $^{b}$} \\
\hline & & Sum of Squares & Df & Mean Square & $\mathrm{F}$ & Sig. \\
\hline & Regression & 8.293 & 3 & 3.764 & 3.921 & $.046^{\mathrm{a}}$ \\
\hline & Residual & 35.959 & 38 & .946 & & \\
\hline & Total & 44.252 & 41 & & & \\
\hline
\end{tabular}

a. Predictors: (Constant), financial incentive pay

b. Dependent Variable: employee performance

\subsection{Regression Coefficient}

In this case, interpretation of beta coefficients means that holding all other independent variables constant, every unit change on incentive pay shall increase employee performance by 0.547 . Therefore, financial incentive as an independent variable has a positive impact on the employee's performance. On the significance, it was noted that the predictor, was significant, since its significant values was less than 0.05 , i.e. Incentive pay, $P$ value $=0.027$.

The multicolinearity tests was also carried out on the independent variable. The tolerance and VIF values for financial incentive were; 0.375 and 2.657, which means that VIF value $<10$ and tolerance value $>0.1$, therefore multicollinearity does not exist. 
Table 4.7: Regression coefficients

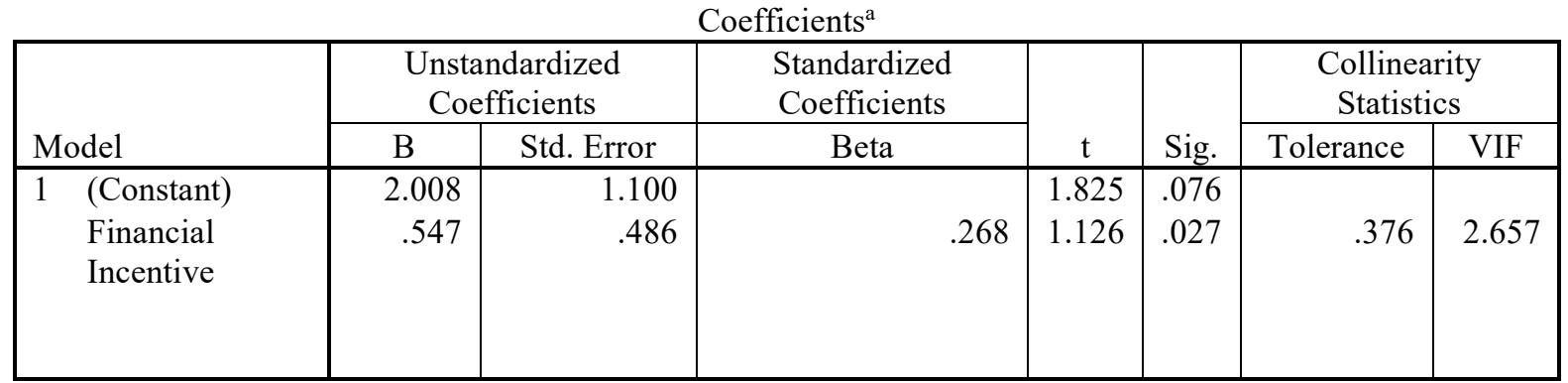

a. Dependent Variable: Employee performance

\subsection{Hypothesis testing}

After the analysis, hypothesis stated earlier part of this paper was tested and from the findings, the hypothesis was accepted and proved true.

Table 3.8: Hypotheses testing

\begin{tabular}{|l|l|l|}
\hline Hypothesis & Coefficient P- Values & Conclusion \\
\hline $\begin{array}{l}\mathrm{H} 0_{2} \text { : The existing incentive pay has significant influence } \\
\text { on performance in University of Nairobi }\end{array}$ & $\mathrm{P}=0.033<0.05$ & Accept $\mathrm{H}_{02}$ \\
\hline
\end{tabular}

\subsection{Conclusion}

Would it be appropriate to conclude that financial incentives positively contribute to enhanced employee performance? The paper's findings indicate so. When the respondents were asked to give a view of the extent to which incentive pay enhances employee performance, they indicated in affirmative as follows: $53.7 \%$ gave great extent, $12.6 \%$ very great extent, $10.5 \%$ moderate extent and $6.3 \%$ low extent. The responses concurred with the review of the literature on financial incentive practices which showed that to effectively enhance employee performance organizations need to invest in their well-being especially the financial aspect (Ghosh, 2005; Mathias, \& Jackson, 2004; Mullius, 2005).

Additionally the study sought to establish influence of incentive pay on performance. It was agreed that bonuses in employees' salaries based on organizational profitability or efficiency gains enhances employee performance, $(\mathrm{Mean}=3.95$, Std. $\mathrm{dev}=0.82)$. It was also agreed that, workers are appropriately and equitably rewarded for their effort, $(\mathrm{Mean}=4.49$, Std. $\mathrm{dev}=0.50)$. Additionally the findings indicated that when employees benefit from incentive pay they enhance their output, (Mean $=4.46$, Std. dev $=0.50)$.

On the other hand positive management strategy earns the loyalty of his workforce, the employees will definitely see themselves as stakeholders in the organization and will be most likely to protect their interest by increasing performance. Well- rewarded employees feel their organization values them. This motivates them to be more dedicated and committed to their employer when their well-being prioritized. The more the employees are motivated the more they perform (Giancola, F. 2011; Hansen, etal, 2012). Organizations that implement such practices with dedication, maintains a competitive edge over their competitors because such practices affects other variables such as competitive advantage, job satisfaction, financial performance, employee turnover, service quality, employee commitment in a positive manner and leads to overall corporate performance. Since this study indeed established that incentive pay is a key human resource factor that has tremendous effect on the employee performance, then organizations should venture into this factor in order to maintain competitive advantage. It is also imperative to conclude that based on the study's findings, there is positive effect of financial incentive on employee performance at the University of Nairobi.

\subsection{Recommendations}

The review of various studies conducted on financial incentives as a yardstick to enhance employees performance indicate that there are other several factors affect employees performance such as attention, recognition, career and self-development. Due to the findings of this study, the following is recommended:

- The need to harmonize the financial incentives in organizations as a means to long term objectives and the strategies of the organization. Additionally they should be evaluated from time to time by conducting a survey among the employees and the provisions should be made to incorporate changes from time to time. The traditions of the organization and the past practices should be kept in mind while restructuring the harmonization aspects.

- Additionally human resources management practices differ from one country to another and from one organization to another, therefore due consideration should be given to the organization and the country's specific environment. 
- The line managers should be involved in the process of the design of the human resources management practices since they deal with the employees in their respective units and may provide valuable insights. There is also a need to critically examine key competitors due to their significant implications with adverse effects on the organization. The power-centre and the political environment prevailing in the organization should be adequately studied.

\subsection{Areas of future research}

The debate on financial incentives as a human resource management practice continues both in organizations and academic circles. The current literature addresses a range of issues relating to human resource management practices and employee performance, although this study contributes to the body of literature on various dimensions, the results are not conclusive. Further research in areas as; effects of human resource management practices on employee retention, turnover and organizational life cycles should be explored.

\section{REFERENCES}

Armstrong, M (2016). Armstrong's handbook of human resource management. London: Kogan Page.

Babbie, E. (2011). The basics of social research, 5th ed. Belmont: Wadsworth.

Beer, M., et al (2005). Human resource management: A general manager's perspective. 6th edition, Free Press, New York.

Boxall P \&Purcell, J. (2016). Strategy and human resource management. London: Palgrave Macmillan.

Chow, W., Christin, N., Chu-Hua, K., Min, H., Chinho, L. \& Hojung, T. (2008). Supply Chain Management in the US and Taiwan: An empirical study. Omega, 36 (5), 665-679.

Elmer b. (1988). Public service and the public interest. Public administration review, 48(2), 601.

Fulmer \& keys (1998). A conversation with Peter Senge: New developments in organizational learning. Organisational dynamics, 27 (2), 33-42. Online. Science direct database. Accessed 03 mar 2019.

Giancola, F. (2011). Examining the job itself as a source of employee motivation. Compensation and Benefits Review, 43 (1), 23-29.

Ghosh, B. (2005). Human resources development and management, $5^{\text {th }}$ edition. New Delhi: Vikas Publishing House PVT Ltd.

Gould-Williams, J. (2004). The effects of 'high commitment' HRM practices on employee attitude: The views of public sector workers. Public Administration, 82(1), 63-81.

Gray, D. E. (2004). Doing research in the real world. London: Sage Publications.

Government of Kenya. (2010). Employment Act, Cap. 226. Nairobi: Kenya Government Printer.

Hansen, F., Smith, M. \& Hansen, R. (2012). Rewards and recognition in employee motivation. Compensation and Benefits Review, 34 (5), 64-72.

International Labour Organization. (2018). World employment social outlook: Trends 2018. Geneva: Document and Publications Production.

Kaiser, L. (2014). "Job satisfaction and public service motivation,” IZA discussion paper no. 7935,

January 2014 (Bonn: Forschungsinstitut zur zukunft der arbeit (institute for the study of labour).

Krejcie, R., \& Morgan, D. (1970). Determining sample size for research activities. Educational and Psychological Measurement, 30, 607-610.

Lawzi, M. (1995). Individuals' attitudes working in public institutions in Jordan towards job incentives. Derasat, Humanities Studies, 22a (6), 759-785.

Mathias, R \& Johnson, J. (2004). Human resource management. Thomson, South-Western: Mason Publishers.

Mugenda, O \& Mugenda A. (2003). Research methods, quantitative and qualitative approaches. Nairobi: Acts Press.

Mullius, L. J (2005). Management and organizational behaviour, $7^{\text {th }}$ Ed.

Ogutu, W. (2014). Perception of the influence of incentives on employee job performance in the Ministry of Education in Kenya. Unpublished Dissertation. UoN Repository.

OECD. (2009). Internationalization of Higher Education: A Policy Brief. Ojiambo: OECD.

Okioga, C.; Onsongo, E. \& Nyaboga, Y. (2014). Quality issues in the expansion of university education in Kenya, The human resource challenges and opportunities', Chinese business review, Vol. 11, No. 6, Pp. 596-605.

Pfeffer, J., (1994). The human equation building profits by putting people first. London: Harvard Business Press.

Pickles, L., Bookbinder, S. \& Watt, C. (1999). Building the HR value chain. Employment Relations Today, 25. 21-23.

Purcell, J. (2004). The HRM-performance link: why, how and when does people management impact on organisational performance? John Lovett Memorial Lecture: University of Limerick.

Rehman, R \& Ali, M A. (2013). Is Pay For Performance The Best Incentive For Employees? Journal of Emerging Trends in Economics and Management Sciences, 4(6), 512-514

Riechi, A. (2010). Demand for regular academic programs offered in Kenya's universities and their relevance to the 
labor market. Discussion Paper, No, 113.

Rubin, A. \& Babbie, E. (2016). Essential research methods for social work. Australia: Cengage Learning.

Schuler, R. (2002). Linking competitive strategies with human management Practices. Academic of Management Executive, 1(3), 209-213.

Staats, E. (1988). Public service and the public interest. Public Administration Review, 48 (2), 601-605.

Storey, J. (2013). Human Resource Management. New York, NY: McGraw-Hill.

UNDP. (2006). Incentive Systems: incentives, motivation and development performance. nd: Conference Paper Series Production Team, Capacity Development Group.

University of Nairobi. (2018). UON Profile: Background. Retrieved February 06, 2018, from http://www.uonbi.ac.ke/about/profile

University of Nairobi. (2012). University of Nairobi Establishment Plan 2012.

\section{Author}

Dorothy Njiraine is the Chairperson and Lecturer, Department of Library and Information Science, University of Nairobi, Kenya. She holds a Doctorate of Library and Information Science (University of Zululand, South Africa2011), MSc. in Information Science (Makerere University, Uganda-2005), MBA (Moi University, Kenya-2012), PGD in Librarianship (Makerere University, Uganda- 1998) and B.A. Hons (University of Nairobi, Kenya- 1989). She is also a member of Kenya Library Association.

Research interests: Knowledge management; Indigenous knowledge; Indigenous knowledge systems; ICT4D; Agricultural information and communication management; Digital libraries and information systems; Management information systems; Information literacy and communication skills Information ethics; Informetrics; Strategic management; Human resource management; Project planning and management; Research methods. 